\title{
United Nations and the Protection of Human Rights of Victims of Terrorism
}

\author{
Sumanta Meher $^{1^{*}} \quad$ Dr. Subramanian Ramamurthy ${ }^{2}$ \\ 1.Research Scholar (Ph.D.) Rajiv Gandhi School of Intellectual Property Law, Indian Institute of Technology, \\ Kharagpur, West Bengal 721302, India \\ 2.Assistant Professor, Rajiv Gandhi School of Intellectual Property Law, Indian Institute of Technology, \\ Kharagpur, West Bengal 721302, India
}

\begin{abstract}
Undoubtedly, Terrorism is a menace to World peace, security and cordial relationship between the States. United Nations has adopted several measures through different resolutions to prevent, and eliminate international terrorism, but in these measures, the rehabilitation of victims of terrorism had not given any importance. However, after the framing of the Global Counter-Terrorism Strategy, the United Nation Organization has taken the initiative to support the victims of terrorism and encourage the States Members to form law and assistance scheme for the victims of terrorist activities. The objective of this paper is to ascertain the present issues relating to terrorism and analyze the initiatives made by the UN in the combating of international terrorism and Support to the victims of terrorism. For that purpose, the paper analyses the international instruments for the countering the terrorism and the initiative made by the different organ of the UN to provide support to the victims of terrorism. The paper also suggests solutions for the benefit of the fighting of terrorism and to provide protection to the basic human rights the victims of terrorism.
\end{abstract}

Keywords: Terrorism, Victims of Terrorism, United Nations, Human Rights.

DOI: $10.7176 / \mathrm{JLPG} / 88-18$

Publication date: August $31^{\text {st }} 2019$

\section{Introduction}

The act of terrorism scatters the harmony and security of the World. The terrorist attacks in the last two decades have shown the worst faces of terrorism. In this period the terrorist attacks have increased enormously. The terrorist's organization are spreading the terror in the world because of the political ideologies, or radical religious beliefs. Such ideologies and extremism have increased the violence and posed a danger to freedom and peace in the world. These attacks posed devastating consequences on human lives. Indeed, terrorist activities are widely considered as the worst threat to Human Rights (Dreher, Axel, Martin Gassebner 2010). This fear and threat need to be thrown away from the phycology of every human beings. However, the States are investing a million of money for the countering the terrorism, but the terrorism is still prevailing to its peak. Moreover, the support to the victims of terrorism hardly finds its place in the counter terrorism tactic of the States. In the absence of a standard policy for the support the victims of terrorism, the sufferings of the victims are hard to be articulated.

A very vital role play by the United Nations (UN) in the combating terrorism and maintaining harmony and security in the world. The UN have adopted several measures through different resolutions to prevent and eliminate the different form of international terrorism (The United Nations through the Substantive resolutions adopted as many as 81 Resolutions, whereas in the Procedural Resolutions the UN has adopted as many as 31 Resolutions for combating terrorism). UN has entrusted a great responsibility to the Security Council under Chapter VII of the Declaration of the UN Charter to take necessary actions to preserve peace and security in the world (Bianchi, Andrea 2004). The Security Council utilizing its power under Chapter VII of the UN Charter and approved some active measures for combating terrorism, and those measures have taken under this chapter is called Chapter VII Resolutions (Zadeh, Mohamad Esmael 2016).

The UN has taken specific initiatives to support the victims of terrorism only after the 9/11 terrorist attacks on the World Trade Center of USA. The General assembly has framed the Global Counter Terrorism Strategy in 2006 and focuses on the support to the victims of terrorism on the Plain I and Plan IV of the Strategy. The General Assembly urged all the Members State to incorporate the assistance scheme for restoration of the victims of terrorist attacks.

\section{The Development of the Concept of 'Terrorism'}

Terrorism is an age-old concept, and the origin can be found in the 'Regime of terror' (Walter, Eugene Victor 1969) or the very conception of the 'State' (Jarvis, Lee, at al. 2014). However, the contemporary situation of terrorism is more drastic then earlier. It is no more a problem concerning only to a particular country or between the few countries. It has become a threat to the entire world, so, the combating of terrorism has become a global movement. The increase in terrorist activities initiated the efforts of combating terrorism after World War I 
(James, Brenda 2013). The manifestation of this matter was held in several meetings under the International Discussion for the harmonization of penal law in the late twenties as well as in thirties (Thomas M. Franck, at al. 1974). These meetings, seated by different delegations representing states and both private international organizations as well as intergovernmental which served to focus attention on the subject. As in earlier years, some fugitive transfer treaties were revised to exclude certain terrorist acts from the exception of "political offenses," thereby making them extraditable.

The movement of combating of International terrorism has been started in 1937 by the League of Nations. The "Convention for Prevention and Punishment of terrorism" was framed by the League of Nations in 1937. The Convention provide a defination of the term 'Terrorism'. Article 1 clause 2, Define the terrorism as "criminal acts directed against a State and intended or calculated to create a state of terror in the minds of particular persons or a group of persons or the general public." But this convention never comes into existence because of the dispute among the Members State regarding some provisions of the Convention. However, the UN and other Regional Organization referred to this convention while debating on the topic of combating of terrorism. Many scholars are also referring to this Convention as literature in their research on counter-terrorism.

So, the efforts of combating of international terrorism have been started years before the establishment of the UN. The endeavor of the UN to prevent terrorist activities has begun after the Tokyo Convention (The Convention on Offences and certain Other Acts Committed on Board Aircraft, 1963). Although, the word 'Terrorism' has not used the legal instrument, through the convention, they try to prevent the terrorist activities. The UN started adopting Resolutions on countering terrorism only after the Munich massacre, where 28 persons including 11 athletes were kidnapped and killed. After the incident, Kurt Waldheim, the then Secretary-General suggested the General Assembly to take account of a measure to prevent terrorism in its proceeding for discussion. So, the Resolutions No.3043 has passed by the General Assembly titled "Measures to prevent terrorism and other forms of violence which endanger or take innocent human lives or jeopardize fundamental freedoms." Since then the General Assembly has adopted as many as eighty-one numbers of Resolutions to counter terrorism. However, the situation is not changed with regard to the concept the term 'terrorism'.

\section{The Term 'Terrorism' and 'Victim of Terrorism' in International Law}

The concept of 'Terrorism' has both national and international dimension, and these dimensions should be taken into consideration while defining the term terrorism. The meaning of the term 'Terrorism' is a controversial concept in the International sphere due to the lack of unanimity amongst the member of the international community. The UN General Assembly Resolution 51/210 on "Declaration on Measures to Eliminate International Terrorism" in the year 1996 proposed a non-binding definition of terrorism by defining terrorism, as "The criminal acts intended or calculated to provoke a state of terror in the general public, a group of persons or particular persons for political purposes are in any circumstance unjustifiable, whatever the considerations of a political, philosophical, ideological, racial, ethnic, religious or any other nature that may be invoked to justify them" (Article 2 of Declaration on Measures to Eliminate International Terrorism, A/RES/51/210, 1996). Prof. Ben Saul (2008) categorically said that the domestic legal systems have their jurisdiction to be flexible, so they have the effective means to explain the terrorism in their national law and also cover the definition propounded by the International Organization. Even after taking several steps the international communities have not come to a universally acceptable definition this itself posed a challenged to combat terrorism (Todd Sandler 2005).

The different terrorist activities have been considered as crime in the international community but the term 'Terrorism' has not find it place in international law as a crime. The UN has been trying to criminalize terrorism at the International level, but it is not acceptable to most of the countries because they have their own views regarding terrorism. However, the 9/11 terrorist attack on the soil of the USA has brought the attention of the leaders of the World on terrorism, and after that the UN has adopted a resolution to criminalize the terrorism (S/RES/1373, 2001). Further in 2004, UN Security Council in its Resolution no. 1566 strived to outline the terrorist act as:

"Criminal acts, including against civilians, committed with the intent to cause death or serious bodily injury, or taking of hostages, with the purpose to provoke a state of terror in the general public or in a group of persons or particular persons, intimidate a population or compel a government or an international organization to do or to abstain from doing any act, which constitute offences within the scope of and as defined in the international conventions and protocols relating to terrorism, are under no circumstances justifiable by considerations of a political, philosophical, ideological, racial, ethnic, religious or other similar nature."

The meaning of the term 'victim' has been clearly defined in transnational law; however, the meaning of its subcategory of the 'victims of terrorism' are ambiguous in international law. The reason behind the ambiguity in the term 'victims of terrorism' is the definition of the term 'terrorism.' As there is an absence of agreement among the supporters of the international community on a specific definition of terrorism has not been arrived. However, to identify the victims of terrorism, the UN General assembly through the "Framework principles for securing the human rights of victims of terrorism" (A/HRC/20/14, 2012) categories the victims of terrorism 
keeping in the mind of the impact of the terrorist activities upon the common people. According to these principles, "The following persons are to be considered as victims of terrorism: (a) natural persons who have been killed or suffered serious physical or psychological injury through the commission of an act of terrorism (direct victims); (b) the next-of-kin or dependents of a direct victim (secondary victims); (c) innocent individuals who have been killed or suffered serious injury indirectly attributable to an act of terrorism (indirect victims); and (d) potential future victims of terrorism" (para 65).

\section{The initiatives of counter terrorism and safeguard of human rights by the UN}

The combating of terrorism is a global movement where every nation of the world and the international and regional organizations have been actively participated. The Organization like the UN, European Union, African Union, Association of Southeast Asian Nations, and other play very significant role to combat terrorism. The UN is the largest organization which consists of 193 countries of the world. The very purpose of the establishment of the UN, after World War II, is to protect the human rights and maintain peace and security of the world and to prevent the reputation such situation (Hans Kelsen 1950, Antonio Cassese 2005). Hence, the endeavor of the UN is remarkable in maintaining harmony in the world. However, one of the greatest threat to human rights in the present scenario is terrorism. The UN has adopted several measures to combat terrorism.

Resolutions of General Assembly for Countering Terrorism

The UN through the Substantive resolutions adopted as many as 81 Resolutions for combating of terrorism. These all resolutions reflects the approach of the General Assembly towards the combating terrorism, which is changing gradually. According to the changing approach of the General Assembly, the Resolutions can be categorized into three different heads (Rupérez, Javier 2006).

The first period is titled as "measure to prevent terrorism." From 1972 to 1991 the General Assembly took measure to prevent terrorism. Even the title of the UN Resolutions relating to terrorism this period was "measure to prevent terrorism." The second period is called "Human Rights and Terrorism" it covers form 1993 to 2001. The basic considerations in the period were the prevention and safeguard of Human Rights from the acts of terrorism. The General Assembly has taken several resolutions to prevent and eliminate terrorism and protect the human rights. In the resolutions, the General Assembly condemned the terrorist activities and called every Member States to unite in order to eliminate terrorism. The third period is called "measure to eliminate terrorism" (Halberstam, Malvina 2002). This period covers from 2001 to present (2016), in this period the General Assembly adopted 60 Resolutions for the elimination of terrorism. In 2006 the General Assembly adopted the Global Counter Terrorism Strategy to counter terrorism effectively.

Resolutions of the Security Council to combat Terrorist Activities

The UN Charter entrusted the prime obligation to the Security Council to preserve peace and security in the world under Article 24. Under Chapter VII, the Council has a wider authority to decide what actions are to be taken in situations involving "threats to the peace, breaches of the peace, or acts of aggression." In those situations, the Council is not restricted to provide recommendations but may take action, together with the use of armed force (Schweigman 2001) "to maintain or restore international peace and security." Decisions are taken under Chapter VII, both concerning martial action and to financial sanctions, are binding on all UN member states.

The measure approved by the Security Council beneath Chapter VII of the UN Charter is apparently called as Chapter VII Resolutions. Most of the Chapter VII resolutions majorly contains two things (Johansson, Patrik 2009). Firstly, in accordance with Article 39, to ascertain the presence of a breach of the peace, a threat to the peace, or an act of aggression. Secondly, to take a decision explicitly under Chapter VII of the UN Charter. However, there is ambiguity regarding the Chapter VII status of a small number of resolutions. For the clearance of meaning a proper definition of Chapter VII resolutions has given by different scholar. It can be lucidly defined as "A Resolution agreed by the Security Council is considered to be a 'Chapter VII resolution' if the resolution replicates a clear willpower that the circumstance under attention establishes a risk to the peace, a breach of the peace, or an act of aggression, or unambiguously or obliquely states that the Council is acting under Chapter VII in the agreement of some or all operative paragraphs."

There is a clear demarcation of combating of terrorism between before and after the year 1992. After 1992 the Security Council started taking resolutions for the elimination of terrorism by invoking Chapter VII of the Charter. Security Council agreed on the Resolution 731 (1992) in the wake of the attacks on two aircraft Pan-Am flight 103 in 1988 and French UTA flight 772 in the year 1989; where the Libyan Arab Jamahiriya a terrorist group has alleged to have possible involvement in the attacks (McNamara, Thomas E 2007). Subsequently, several resolutions have been adopted in the matter Libyan Arab Jamahiriya terrorist group, Taliban and other terrorist activities which make a distinct impact in the world.

\section{Changing paradigm after the $9 / 11$ attack}

However, the paradigm has completely changed after the September 11, 2001 of US terrorist's attacks, one day 
after, the Security Council by invoking Chapter VII universally adopted resolution 1368, the objective of the resolution laying down in its enforcement of the individual's rights or combined self defense under the Article 51 of the UN Charter and which solemnly urge upon all Member States to act together "to bring to justice the perpetrators, organizers and sponsors" of terrorists acts and to "redouble their efforts to prevent and suppress" them (Rostow, Nicholas 2001). This Resolution is deliberated as a paradigm shift of the legitimized the use of force to fight terrorism. Again the Security Council, performing under Chapter VII of the UN Charter, approved the Resolution 1373. This resolution has adopted within the two weeks of the attack and take a reliable measure to eliminate terrorism. The purpose of the resolution is to hinder any form of terrorist. The resolution recalls the earlier resolution of combating terrorism. UN encouraged the member States to share their intelligence regarding the terrorist group for effectively countering terrorism. This resolution obliges all the states to frame domestic legislation for countering terrorism and ratify the international conventions on terrorism.

\subsection{The Committees on combating terrorism}

The Security Council has made the Counter Terrorism Committee within the Resolutions 1373 in the year 2001. This committee is a subordinate part of the Security Council which constituted all 15 the members of the Security Council and entrusted with watching the compliance with the resolution (Jackson, Richard 2005). The Committee was directed to initiate its work by collecting the reports from the Member State regarding the measures taken to the implementation of the Council's decisions. The objective of the committee is also to assist all the Member States (Foot, Rosemary 2007).

\subsection{The Counter Terrorism Committee Executive Directorate}

One of the main hurdles of the counter-terrorism is the insufficiency of the experts group. After establishment of the Counterterrorism Committee the inadequacy of these experts' persons and resources has revitalized. A proposal adopted by the Committee in 2004, to establish a Counter-Terrorism Committee Executive Directorate, which will be directed by an Executive Director who would be engaged at the Assistant Secretary-General and would run under the suggestion of the Committee (Rosand, Eric 2006). In 2004, The Council has endorsed the report in its Resolution No. 1535. The Executive Director has been appointed through the resolution and approved of the Security Council.

\subsection{The Counter Terrorism Implementation Task Force}

The Secretary-General has made a foundation of the Counter-Terrorism Implementation Task Force (CTITF) coordination framework in 2005. It is created in order to attain greater unity for the perseverance and strengthen for coordination and coherence within the UN system of counter-terrorism (Pandya, Abhinav 2016). It was constructed in the Department of Political Affairs of the UN through General Assembly resolution A/RES/64/235 and work under the supervisions of the Secretary-General for Political Affairs. The Task Force provided with a dedicated secretariat in the form of the CTITF Office.

\subsection{Global Counter terrorism Strategy}

The UN General Assembly approved the "Global Counter Terrorism Strategy" on 2006. The Strategy is a unique global instrument to strengthen national, regional and international efforts to combat terrorism (Romaniuk, Peter 2010). Through this strategy, all Member States have given their approval for the first time for a standard plan and functioning approach to combating of terrorism. This step of accord among the Member reflecting a transparent indication that the terrorist activities are intolerable in all its forms. To prevent the terrorist activities, both individual and comparative action need to be taken. Those concrete actions include a wide collection of measures ranging from reinforcement the State's capability to counter terrorist threats to better harmonizing the UN systems to fight terrorist activities (The Counter-Terrorism Implementation Task Force).

\subsection{Comprehensive Convention on International Terrorism}

India has suggested the draft Convention on International Terrorism on 17 December 1996 to the "UN General Assembly's Ad Hoc Committee" was formed by Resolution 51/210 of on Terrorism. The Comprehensive Convention on Terrorism intends to prohibit all forms of international terrorism. It also denies terrorists, their supporters and financiers' access to arms, funds, and safe havens. It has been pending in the Assembly since 1996 because of lack of the consensus of the member states regarding the many providers of this convention like; definition, extradition of terrorists etc.

\section{Initiatives of the UN for the Assistance to the Victims of Terrorism}

The UN has taken initiatives to recognize the rights of all the victims through different guidelines and resolutions. The UN has started recognizing the position of the victims of terrorism after the "Global Counter-Terrorism Strategy 2006." From this Global Counter-Terrorism Strategy, a separate trend has started to focus on the 
assistance to the victims of terrorism in international law. However, European countries have started similar trends long back to provide assistance to the victims of terrorism.

UN Global Counter-Terrorism Strategy has four pillars, and out of these, two pillars (Pillar I and Pillar IV) has highlighted to the support of the victims of terrorism. Under these pillars the UN seeks to "promote international solidarity in support of victims, and also stresses the need to promote and protect the rights of victims of terrorism and their families and facilitate the normalization of their lives, and the United Nation identifies the dehumanization of victims of terrorism." Section I, paragraph 8 of the UN Global CounterTerrorism Strategy has explained "To consider putting in place, voluntarily, national systems of assistance that would promote the needs of victims of terrorism and their families and facilitate the normalization of their lives. In this regard, we inspire States to request the relevant UN units to help them to cultivate such national systems. We will also strive to promote international solidarity in support of victims and foster the involvement of civil society in a global campaign against terrorism and for its condemnation. This could include exploring at the General Assembly the possibility of developing effective mechanisms assistance to victims." Also, Section IV this Strategy has elucidated "We resolve to undertake the following measures, reaffirming that the promotion and protection of human rights for all and the rule of law is essential to all components of the Strategy and stressing the need to promote and protect the rights of victims of terrorism."

Secretary-General of the UN has formed the Counter-Terrorism Implementation Task Force (CTITF) in the year 2005. 'CTITF' also endorsed by the General Assembly through the UN Global Counter-Terrorism Strategy and approved in 2006. The main purpose to form the CTITF is to make stronger harmonization and make the consistency of counter-terrorism efforts of the UN. The Task Army consists of nearly 38 international bodies which by virtue of their work have a stake in multifaceted Combat terrorism efforts. Each State makes contributions consistent with its own mandate.

The objective of the 'CTITF' is to make the best use of each entity by providing as one and to support the Member States implementing the 4 pillars of the Global Strategy. The 4 pillars are "Measures to address all the conditions which are conducive to the spread of terrorism; Measures to prevent and combat terrorism; Measures to build states' capacity to prevent and combat terrorism and to strengthen the role of the UN system in that regard; Measures to ensure respect for human rights for all and the rule of law as the fundamental basis for the fight against terrorism."

\subsection{The Working Group on Victims of Terrorism}

The 'CTITF' has made a operational group called "Supporting and Highlighting Victims of Terrorism". The purposes of this "Working Group" are "to strengthen the support of, the effective implementation of Pillar I and Pillar IV of the UN Global Counter-Terrorism Strategy related to victims of terrorism." The 'CTITF' and it is Working Group on Supporting and Highlighting Victims of Terrorism in June 2014 open the UN Victims of Terrorism Support Portal. "The Portal facilitates access to resources for victims, their families and communities - be it psychosocial support, understanding how to access national criminal justice systems or rehabilitation opportunities offered by the Member States. The Portal also demonstrates the international community's solidarity with victims."

\subsection{UN Symposium on supporting victims of terrorism}

Ban Ki-moon, The UN Secretary General organized a Symposium on the main theme of Supporting Victims of Terrorism. The main goal of Symposium is to provide a forum to experts, Member States, regional organizations, the victims, and the media to discuss with regard to the solid steps taken for the assistance to the victims. During th ediscussion, the experts share the best activities of the all the state to support the victims of terrorism.

In the Symposium, these following eight recommendations have been identified to support the victims of acts of terrorism. The recommendations are "a virtual networking, communication and information hub for victims of terrorism, Government officials, experts, service providers, and civil society; Strengthen legal instruments at both the international and national levels, providing victims of terrorism with legal status and protecting their rights; Establish easily accessible health services that can provide victims with comprehensive support over the short, medium and long term; Create an international rapid response team for victims' support; financial support to victims; Improve the capacity of the UN to assist survivors and families of staff killed or injured in terrorist attacks against it; Engage in a global awareness campaign supporting victims of terrorism; Improve media coverage of victims of terrorism"

6.3. UN Resolution on Protection of human rights and fundamental freedoms while countering terrorism In 2010, the General Assembly through the Resolution "Protection of human rights and fundamental freedoms while countering terrorism" (A/RES/64/168, 2010) has the impulsed to the Members States for developing and implementing for the assistance and support of programme for victims of terrorism in accordance to the national resources. The UN also directs the UN Office on Drugs and Crime (UNODC) to assist the Member States for the 
establishment of the victim's assistance programme. In April 2017, also the General Assembly had adopted a resolution and encouraged the States to provide appropriate assistance and rehabilitation for victims of terrorism following relevant national laws within available resources (Effects of terrorism on the enjoyment of all human rights, A/HRC/RES/34/8, 2017).

\subsection{The Good Practices in Supporting Victims of Terrorism}

The General Assembly in its Resolution 66/178 request the UNODC's Terrorism Prevention Branch to create a Good Practices in Supporting Victims of Terrorism within the Criminal Justice Framework. This book is a tool which contains a collection of good practice for the Member States intending to strengthen national legislation and institutions regarding victims of terrorism, especially during criminal justice proceedings. The General Assembly on 19 December 2011 "Requests the United Nations Office on Drugs and Crime, within its mandate, to continue to develop specialized legal knowledge in the area of counter-terrorism and pertinent thematic areas of relevance to the mandate of the Office and to provide assistance to requesting Member States with regard to criminal justice responses to terrorism, including, where appropriate, nuclear terrorism, the financing of terrorism and the use of the Internet for terrorist purposes, as well as assistance to and support for victims of terrorism"

\subsection{UN Conference on Human Rights of Victims of Terrorism 2016}

The organs of the UN have organized a Conference in 2016 to discuss on the topics of awareness on the rights of victims of terrorism. The aim of the Conference was also to examine how States can make stronger their Legal framework to protect and support victims. The conference also echoed on the testimony on the "Framework Principles for Securing the Human Rights of Victims of Terrorism" (A/HRC/20/14) on the advancement and safeguard of human rights and fundamental freedoms while fighting terrorism. The report made a set of 14 commendations for the Member to uphold their international obligations in this regard. Besides, the conference observed into the role that victims can play in preventing the spread of terrorism.

6.6. International Day of Remembrance of and Tribute to the Victims of Terrorism

In October 2017, the UN General Assembly has adopted a Resolution to declare 19th August as the International Day of Remembrance of and Tribute to the Victims of Terrorism. The Resolution also advocates to support and respect the victims and survivors of terrorist activities and to promote and protect their human rights and fundamental freedoms. The UN General Assembly invites all Member States, different Organizations within the UN, other international organizations, and civil society, including non-governmental organizations and individuals, to observe International Day Remembrance of and Tribute to the Victims of Terrorism within their capability.

\section{Challenges confronted during combating of terrorism}

The very fast hurdle comes in the way of combating terrorism is the universally accepted definition of "Terrorism". The very concept of "one man's terrorist is another man's freedom fighter" is the obstruction in the way of framing a consensual definition. However, the present scenario of society is different from the earlier movement of political ideology. Now each and every country is severely affected by terrorism. So there is a need for a precise definition of terrorism. Several endeavors have made in different point of time like; in 1937 through Convention for Prevention and Punishment of Terrorism, during the debate in General Assembly in 1973 and more emphasis can be given to the debate to pass the Resolution 1373 (Rosand, Eric 2003); and moreover the Draft Convention on International Counter-Terrorism which is in deadlock. Even several research scholar also try to frame a concise definition of 'terrorism,' some notable scholars are Alex. P. Schmid (2011) and Ben Saul (2006).

The second significant challenges encountered by the international community is the lack of specific convention for counter-terrorism. The UN has adopted several conventions addressing specific crimes committed by the terrorists without using the word "terrorism," but the UN is unable to adopt a specific convention on terrorism. However, a draft convention on counter-terrorism was proposed by India in 1996 which intends to criminalize all forms of international Terrorism and deny terrorist, their finances and supporters access to funds, arms and safe haven. The negotiation for this convention was deadlock, but currently, a negotiation has been underway at the UN General Assembly (Hmoud, Mahmoud 2006).

The Comprehensive Convention on International Terrorism (CCIT) is a convention which intends to criminalize all forms of international Terrorism and deny terrorist, their finances and supporters access to funds, arms and safe haven. Some of the specifications of the Comprehensive Convention on International Terrorism are; first, a universal definition of Terrorism has prescribed. Second, the convention ban on all groups regardless of country of operation cut off access to funding and safe heavens. Third, its prosecution of all groups including cross border groups. Moreover, fourthly, it obliged all the Member states to amend their domestic law relating to 
terrorism and extradition.

The third, significant challenges confronted while countering terrorism is the harboring and aiding to the terrorists. Some countries are giving shelter to the terrorist's organization and actively participating in the cross border terrorism. Hence, the international community needs to declare these States as "Terrorist State," and no country will make any relations with those countries.

Fourthly, the absence of a general standard of norms for the support to the victims of terrorism makes a hurdle in the way to rehabilitate the lives of the affected persons. The human rights of the victims of the terrorist attacks cannot be protected without a proper mechanism. The General Assembly through its resolution urged the Members State to frame a mechanism in their domestic law the available resources. However, only a few countries have framed a special law or assistance scheme to provide assistance to the victims of terrorism.

\section{Suggestions and Conclusion}

There is no second opinion for the assertion that "terrorism is the biggest threat to the human civilization." For this menace, a collective effort has to be taken for combating of terrorism and protection of human rights. It has spread throughout the world, so each state needs to joint their hand for combating of terrorism. In another word, international cooperation will be the way to eliminate terrorism and preserve human rights. In this regard Chapter, VII of the Charter has opened a way to frame measure appropriate for the demand of this situation. Chapter VII Resolutions is more effective because this chapter obliged the member States to adopt the measure taken under it. Furthermore, we need to reach a precise and universal definition of terrorism. So, the member States can ratify the treaties relating to terrorism and adopt the basic human rights law in their countries.

The initiative taken by various organs of the United Nation Organisation to support the victims of terrorism become a positive move to encourage the States Members to form law and assistance scheme for the victims of terrorist acts; however, the concept is very tender in International sphere which need to be developed so as to set a benchmark for the States Member. In the various Resolutions the UN has urged the States Member to implement the necessary mechanism to support the victims of terrorist attacks, but none of the Resolutions provide a standard for of mechanism which has to be followed by the States Member. The UN has published various books relating to the Good Practice and Support to the Victims of Terrorism but these book depicted some of the scholar literature and the mechanism adopted by various countries. 19th August has declared by the General Assembly to observe as the "International Day of Remembrance of and Tribute to the Victims of Terrorism" but there is less enthusiasm among the States Member to celebrate the day. A general guideline and standard mechanism to support the victims of terrorist acts need to be adopted by the United Nation so as to follow by the States Member.

\section{References}

Antonio Cassese (2005), International Law, OUP Oxford, p.323

Ben Saul (2008), Defining 'terrorism' to protect human rights, Fride Research Paper, 20: 10.

Bianchi, Andrea (2004), ed. enforcing international law norms against terrorism, Bloomsbury Publishing. p. xix.

Dreher, Axel, Martin Gassebner (2010), at al. "Does terrorism threaten human rights? Evidence from panel data." 53, no. 1, the Journal of Law and Economics, 66: 65-93.

Foot, Rosemary (2007). "The United Nations, counter terrorism and human rights: institutional adaptation and embedded ideas." 29 no.2, Human Rights Quarterly, 489-514, 492.

Halberstam, Malvina (2002). "Evolution of the United Nations Position on Terrorism: From Exempting National Liberation Movements to Criminalizing Terrorism Wherever and by Whomever Committed," 41 The Colum. J. Transnat'l L. 573.

Hans Kelsen (1950), The Law of the United Nations: A Critical Analysis of Its Fundamental Problems Volume 11, The Law book Exchange, Ltd., p.19;

Hmoud, Mahmoud (2006). "Negotiating the Draft Comprehensive Convention on International Terrorism Major Bones of Contention." 4.5, Journal of International Criminal Justice 1031-1043.

Jackson, Richard (2005). Writing the War on Terrorism: Language, Politics and Counter-Terrorism. (Manchester University Press).

James, Brenda (2005), "Global Terrorism", 20 Routledge, (2013); J. LUTZ, "Terrorism: Origins and Evolution", Springer,: 160-161.

Jarvis, Lee, at al. (2014). "State terrorism research and critical terrorism studies: an assessment." 7, no. 1, Critical Studies on Terrorism, 44: 43-61.

Johansson, Patrik (2009). "The humdrum use of ultimate authority: defining and analyzing Chapter VII resolutions." 78, no 3, Nordic Journal of International Law 309-342.

McNamara, Thomas E (2007). "Unilateral and Multilateral Strategies against State Sponsors of Terror: A Case Study of Libya, 1979 to 2003." Uniting against terror: cooperative non-military responses to the global terrorist threat 83-122. 
Pandya, Abhinav (2016). "Evaluation of Counter-Terrorism Committee." 4.8, PARIPEX-Indian Journal of Research.

Romaniuk, Peter (2010). Multilateral counter-terrorism: the global politics of cooperation and contestation. P. 34, Routledge.

Rosand, Eric (2003). "Security council resolution 1373, the counter-terrorism committee, and the fight against terrorism." 97.2, the American Journal of International Law 333-341.

Rosand, Eric (2006). ". The Un Security Councils Counter-terrorism Efforts." In Swords into Plowshares: Building Peace through the United Nations, pp. 73-83. Brill Nijhoff,

Rostow, Nicholas (2001). "Before and after: The changed UN response to terrorism since September 11th." 35 Cornell Int'l LJ 475.

Rupérez, Javier (2006). "The United Nations in the Fight against Terrorism." Lecture to the 132nd International Senior Seminar (Statement by the CTED Executive Director), Tokyo, Japan. Available at: http://www.un.org/sc/ctc/documents/tokyo_lecture. pdf.

Saul, Ben (2006).. Defining terrorism in international law. Oxford University Press on Demand.

Schmid, Alex P (2011). The definition of terrorism. Routledge Handbooks Online.

Schweigman pages 34-35 (2001).

The Counter-Terrorism Implementation Task Force (CTITF) https://www.un.org/counterterrorism/ctitf/en/unglobal-counter-terrorism-strategy, visited 5 November, 2016.

The League of Nations was signed "Convention on the Prevention and Punishment of Terrorism" on November 16,1937

The United Nations Global Counter-Terrorism Strategy, A/RES/60/288, (2006)

Thomas M. Franck, at al (1974). "Preliminary Thoughts towards an International Convention on Terrorism," 68 American Journal of International Law.69.

Todd Sandler, Collective versus unilateral responses to terrorism, In Policy Challenges and Political Responses, Springer, 75-93 Boston, MA (2005)

Walter, Eugene Victor (1969). Terror \& resistance: a study of political violence, with case studies of some primitive African communities. Vol. 1. New York: Oxford University Press.

Zadeh, Mohamad Esmael, at al. (2016). "Analysis of International Terrorism Criminography in the Event of September 11th, 2001.” J. POL. \& L. 138. 